\title{
MENINGKATKAN PRESTASI BELAJAR MATEMATIKA MENGGUNAKAN MEDIA REALIA PADA MATERI BANGUN DATAR
}

\author{
ABDUL ROKHIM \\ SMK Negeri 1 Bangil Kabupaten Pasuruan \\ E-mail : abdulrokhim675@gmail.com
}

\begin{abstract}
ABSTRAK
Tujuan penetilian ini adalah untuk meningkatkan prestasi belajar matematika menggunakan media realia pada siswa kelas XI Listrik 1 SMK Negeri 1 Bangil Kabupaten Pasuruan tahun pelajaran 2019/2020. Penelitian ini dilakukan karena rendahnya rata-rata nilai prestasi belajar matematika kelas XI Listrik 1 di SMK Negeri 1 Bangil kabupaten Pasuruan pada pokok bahasan Bangun Datar. Penelitian ini merupakan penelitian tindakan kelas yang terdiri dari dua siklus, dalam satu siklus terdapat empat tahapan yaitu perencanaan (planning), pelaksanaan/tindakan (action), pengamatan (observation), dan refleksi (reflection). Penggunaan media realia dimaksudkan untuk mengkonkritkan pembelajaran matematika yang abstrak tentang bangun datar sehingga dapat memotivasi siswa untuk belajar matematika. Setelah diadakan evaluasi melalui tes tertulis diperoleh data yaitu pada siklus I, nilai rata-rata kelas 69,72 dan dari 36 siswa terdapat 22 siswa (61,1\%) sudah mencapai nilai ketuntasan yaitu $\geq 70$. Sedangkan pada siklus II hasil evaluasi diperoleh rata-rata kelas 79,58 dan terdapat 34 siswa $(94,4 \%)$ sudah mencapai nilai ketuntasan $\geq 70$. Dengan demikian penggunaan media realia dapat meningkatkan prestasi belajar matematika.
\end{abstract}

Kata Kunci : Prestasi Belajar, Bangun Datar, Media Realia

\section{PENDAHULUAN}

Peningkatan mutu pendidikan dasar dan menengah, tidak lepas dari bagaimana program kegiatan belajar mengajar dilaksanakan. Program kegiatan belajar mengajar perlu disiapkan sematang mungkin sebelum seorang guru mengolah kelas agar tercapai suatu tujuan yang diinginkan yaitu peningkatan prestasi belajar siswa. Dalam upaya untuk meningkatkan prestasi belajar siswa tidak terlepas dari peranan guru sebagai pengelolaan sistem pembelajaran. Didalam sistem pembelajaran terdapat komponen-komponen yaitu tujuan pembelajaran, bahan pembelajaran, pembelajar, strategi pembelajaran, metode pembelajaran, sumber belajar, media pembelajaran dan penilaian pembelajaran.

Pembelajaran dikatakan efektif dan efisien jika sebagian besar dari siswa menyerap isi bahan pembelajaran dengan baik. Agar isi pesan (bahan pelajaran) dapat diserap siswa secara maksimal sesuai tujuan pembelajaran yang diharapkan perlu menggunakan media pembelajaran yang tepat sebagai pembawa isi pesan tersebut. Karena media pembelajaran pada hakekatnya merupakan penyalur pesan-pesan pembelajaran yang disampaikan oleh sumber pesan (guru) kepada penerima pesan (siswa) dengan maksud agar pesan-pesan tersebut dapat diserap dengan cepat dan tepat sesuai dengan tujuan (Teoti Sukamto dan Winataputra.1997).

Selain peranan guru, pemerintah juga telah berupaya mengadakan pembaharuan diberbagai sektor pendidikan. Salah satu upaya yang dilakukan oleh pemerintah adalah penyempurnaan kurikulum, tak terkecuali kurikulum matematika. Agar lulusan pendidikan nasional memiliki keunggulan kompetitif dan kooperatif sesuai standar mutu nasioanal dan internasional, kurikulum perlu dikembangkan dengan berbasis kompetensi. Kemampuan matematika yang dipilih dalam kurikulum matematika ini dirancang dan disesuaikan dengan kemampuan dan kebutuhan siswa, serta memperhatikan perkembangan pendidikan matematika didunia sekarang ini. Walaupun pemerintah sudah berusaha mensosialisasikan perubahan kurikulum ini disekolah-sekolah, tapi pelaksanaannya ditingkat sekolah-sekolah masih banyak dijumpai kendala. Pada praktek pembelajaran matematika disekolah pada 
umumnya guru masih tetap menggunakan pendekatan ceramah, tanya jawab dan pemberian tugas.

Berdasarkan pengamatan peneliti (guru kelas), diketahui bahwa masalah utama pembelajaran Matematika di kelas XI Listrik SMK Negeri 1 Bangil yaitu kemampuan menghitung luas dan keliling bangun datar sangat rendah. Dari kenyataan tersebut peneliti berpendapat bahwa pembelajaran Matematika tidak cukup hanya dengan menggunakan metode ceramah dan tanya jawab saja, tetapi juga harus menggunakan cara mengajar yang lain. Salah satunya adalah dengan menggunakan media realia (benda nyata atau benda konkrit) yang bisa membantu siswa mengkonkritkan konsep-konsep Matematika yang abstrak. Sebab menurut teori perkembangan intelektual, siswa SMK kebanyakan berada pada tahap operasi abstrak, meskipun beberapa siswa kesulitan dalam mengkonkritkan yang abstrak. Pada tahap ini anak telah mampu melihat obyek secara simultan, tetapi belum mampu berabstraksi. Media realia (benda nyata atau benda konkrit) adalah alat penyampai informasi yang berupa benda atau objek yang sebenarnya dan tidak mengalami perubahan yang berarti. Media realia (benda nyata atau benda konkrit) dapat dihadirkan dalam proses belajar mengajar baik di dalam kelas maupun di luar kelas.

Melalui media realia memungkinkan siswa menemukan konsep-konsep generalisasi di dalam Matematika dan siswa dapat belajar sambil mengobservasi dari konkret ke abstrak. Siswa tidak hanya mendengarkan informasi tetapi siswa juga mengerjakan sesuatu, sehingga proses penanaman informasi yang dibentuk siswa akan menjadi lebih permanen. Menurut Bahri (2002), melalui media realia (benda nyata atau benda konkrit) daya serap siswa terhadap bahan pelajaran yang sulit dan rumit akan dapat diatasi, siswa akan lebih mudah memahami konsep dan prinsip, dapat melahirkan umpan balik yang baik, serta dapat memotivasi semangat belajar siswa. Sehingga dalam pembelajaran Matematika, penggunaan model dan pendekatan yang tepat sangat diperlukan. Guru hendaknya memilih dan menggunakan metode pendekatan yang banyak melibatkan siswa aktif dalam belajar, baik secara fisik memiliki keunggulan kompetitif dan kooperatif dalam berbagai bidang khususnya bidang studi Matematika (Herman Hudojo, 2005).

Berdasarkan uraian diatas rumusan masalah yang dapat dirumuskan adalah Apakah melalui penggunaan media realia dapat meningkatkan prestasi belajar matematika pokok bahasan bangun datar pada siswa kelas XI Listrik 1 SMK Negeri 1 Bangil Kabupaten Pasuruan Tahun Pelajaran 2019/2020?

Manfaat dari penggunaan media realia (benda nyata atau benda konkrit) bagi siswa untuk mempermudah penguasaan materi pelajaran matematika pokok bahasan bangun datar yaitu menghitung luas dan keliling bangun datar. Sedangkan manfaat bagi guru mengalami sendiri proses tindakan perbaikan pembelajaran yaitu meningkatkan prestasi belajar matematika materi menghitung luas dan keliling bahasan bangun datar dengan menggunakan media realia (nyata) sebagai pengalaman untuk perbaikan selanjutnya.

Kelebihan menggunakan media realia (benda nyata atau benda konkrit) yaitu dapat memberikan kesempatan semaksimal mungkin pada siswa untuk mempelajari sesuatu atau melaksanakan tugas-tugas dalam situasi nyata dan memebrikan kesempatan kepada siswa untuk mengalami sendiri situasi yang sesungguhnya serta melatih keyterampilan mereka dengan menggunakan sebanyak mungkin alat indra. Sedangkan kelemahan menggunakan media realian (benda nyata atau benda konkrit) yaitu biaya yang digunakan tidak sedikit, jika membawa siawa ke berbagai tempat di luar sekolah mengandung resiko dalam bentuk kecelakaan.

\section{METODE PENELITIAN}

Proses dan Hasil Belajar mata pelajaran Matematika merupakan bahan untuk menyusun rencana pelaksanaan pembelajaran dan penelitian tindakan kelas. Dalam hal ini guru sebagai peneliti menetapkan materi dan strategi pembelajaran agar kualitas pembelajaran lebih baik, juga menyiapkan metode pembelajaran dan model pembelajaran yang cocok serta 
media realia sebagai alat bantu untuk mengkonkritkan konsep matematika yang dianggap abstrak.

Penelitian ini merupakan Penelitian Tindakan Kelas dengan dua siklus. Tempat penelitian di SMK Negeri 1 Bangil Kabupaten Pasuruan. Waktu penelitian ini dilakukan pada bulan Agustus sampai dengan Oktober 2019. Mata pelajaran yang menjadi sasaran penelitian ini adalah mata pelajaran matematika kelas XI khususnya untuk kompetensi dasar menghitung luas dan keliling bangun datar. Sasaran dalam penelitian ini adalah siswa kelas XI Listrik 1 SMK Negeri 1 Bangil kabupaten Pasuruan Tahun Pelajaran 2019/2020 yang berjumlah 36 siswa.

Penelitian Tindakan Kelas adalah suatu bentuk kajian yang bersifat sistematis reflektif oleh pelaku tindakan untuk memperbaiki kondisi pembelajaran yang dilakukan. Adapun tujuan utama dari penelitian tindakan kelas adalah untuk memperbaiki/meningkatkan pratek pembelajaran secara berkesinambungan, sedangkan tujuan penyertaannya adalah menumbuhkan budaya meneliti di kalangan guru (Mukhlis, 2000: 5).

Sesuai dengan jenis penelitian yang dipilih, yaitu penelitian tindakan kelas, maka penelitian ini menggunakan model penelitian tindakan dari Kemmis dan Taggart dalam Arikunto (2007: 97), yaitu berbentuk spiral dari siklus yang satu ke siklus yang berikutnya. Setiap siklus meliputi planning (rencana), action (tindakan), observation (pengamatan), dan reflection (refleksi). Langkah pada siklus berikutnya adalah perncanaan yang sudah direvisi, tindakan, pengamatan, dan refleksi. Sebelum masuk pada siklus 1 dilakukan tindakan pendahuluan yang berupa identifikasi permasalahan. Siklus spiral dari tahap-tahap penelitian tindakan kelas dapat dilihat pada gambar 1 berikut :

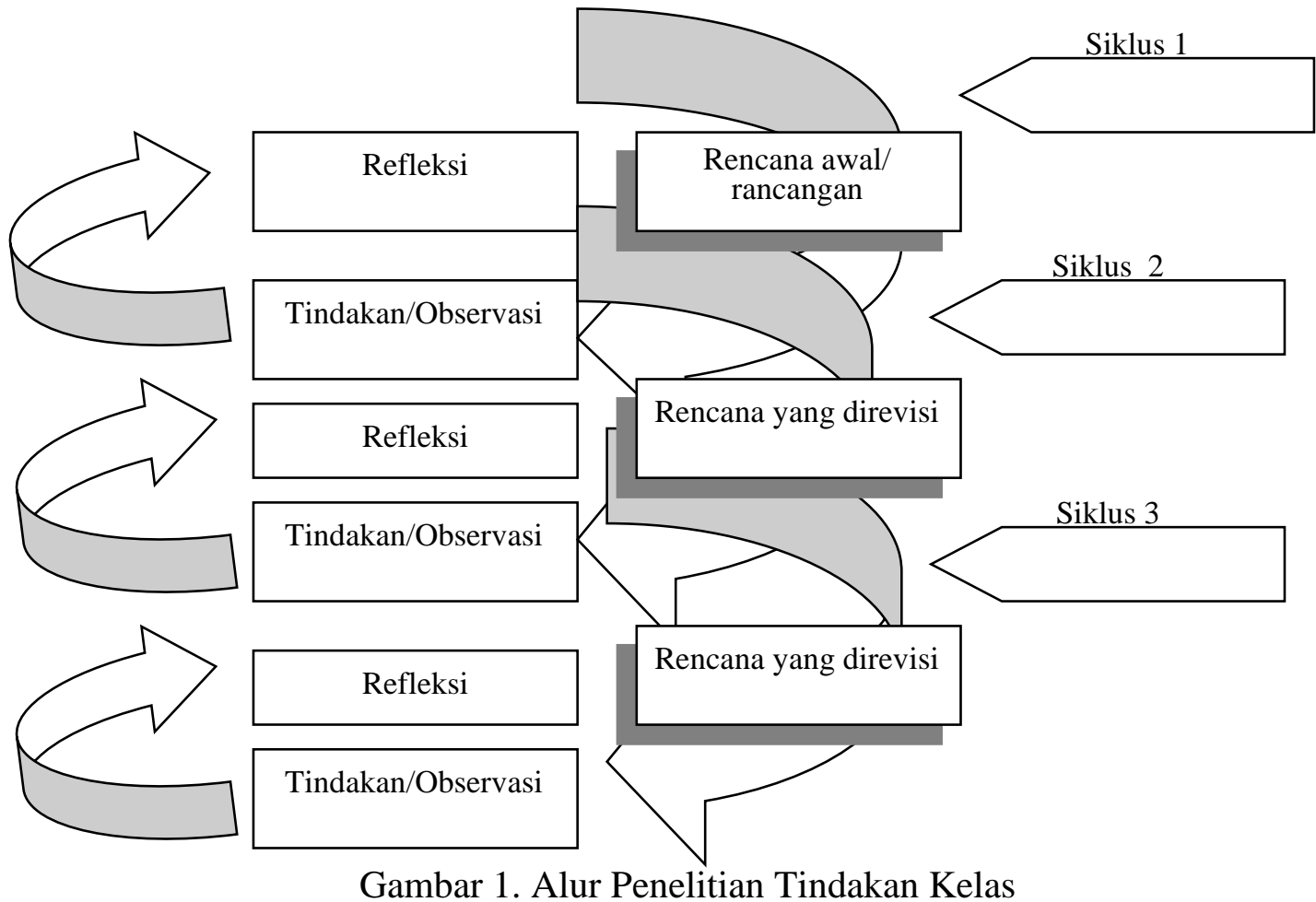

Alur penelitian tindakan kelas menurut Kemmis dan Taggart yang berbentuk spiral dari siklus yang satu ke siklus yang berikutnya adalah: (1) Rancangan/rencana awal, sebelum mengadakan penelitian peneliti menyusun rumusan masalah, tujuan dan membuat rencana tindakan, termasuk di dalamnya instrumen penelitian dan perangkat pembelajaran, (2) Kegiatan dan pengamatan, meliputi tindakan yang dilakukan oleh peneliti sebagai upaya membangun pemahaman konsep siswa serta mengamati hasil atau dampak dari diterapkannya metode pembelajaran media realia, (3) Refleksi, peneliti mengkaji, melihat dan 
mempertimbangkan hasil atau dampak dari tindakan yang dilakukan berdasarkan lembar pengamatan yang diisi oleh pengamat, dan (4) Rancangan/rencana yang direvisi, berdasarkan hasil refleksi dari pengamat membuat rancangan yang direvisi untuk dilaksanakan pada siklus berikutnya.

Pada tahap refleksi dilakukan berdasarkan data yang diperoleh peneliti dan teman sejawat (observer) persiklus adalah: (1) Jika siklus 1 sudah memenuhi kriteria ketuntasan kelas yaitu $\geq 80 \%$ mencapai nilai $\geq 70$ maka siklus 2 tidak perlu dilaksanakan dan jika siklus 1 belum memenuhi kriteria ketuntasan maka perlu diadakan siklus 2, (2) Jika siklus 2 sudah memenuhi kriteria ketuntasan kelas yaitu $\geq 80 \%$ mencapai nilai $\geq 70$ maka siklus 3 tidak perlu dilaksanakan dan jika siklus 2 belum memenuhi kriteria ketuntasan maka perlu diadakan siklus 3 dan seterusnya, dan (3) Dalam setiap siklus dikenai perlakuan yang sama (alur kegiatan yang sama) dan membahas satu sub pokok bahasan yang diakhiri dengan tes formatif di akhir masing siklus.

Instrumen yang digunakan dalam penelitian ini adalah Tes Formatif. Tes ini disusun berdasarkan tujuan pembelajaran yang akan dicapai dan digunakan untuk menghitung kemampuan pemahaman siswa terhadap materi luas dan keliling bangun datar. Tes formatif ini diberikan pada setiap akhir siklus dalam bentuk soal obyektif. Hasil tes formatif diakhir siklus ini yang digunakan sebagai dasar peningkatan prestasi belajar.

Untuk menganalisis tingkat keberhasilan atau presentase keberhasilan siswa setelah proses belajar mengajar setiap siklus dilakukan dengan cara memberikan evaluasi berupa soal tertulis pada setiap akhir siklus. Analisis ini dihitung dengan menggunakan statistik sederhana yaitu: (1) Menghitung persentase Hasil Belajar siswa (daya serap) persiklus dengan menggunakan rumus :

$$
\text { Persentase }(\%)=\frac{\text { Jumlah jawab benar }}{\text { Nilai maksimum }} \times 100 \%
$$

dan (2) Menghitung persentase ketuntasan kelas dengan menggunakan rumus :

$$
\text { Ketuntasan Kelas }=\frac{\text { jumlah. siswa yang tuntas belajar }}{\text { jumlah siswa }} \times 100 \%
$$

(Ngalim, $2006: 11)$

Siswa secara berkelompok atau satu kelas dianggap tuntas belajar bila ketuntasan kelas mencapai $\geq 80 \%$ dari jumlah siswa yang mencapai daya serap $\geq 70$ (kriteria baik)

\section{HASIL DAN PEMBAHASAN}

Input yang berasal dari tahapan evaluasi (evaluation) akan sangat berguna untuk tahapan analisis (analysis) pada pengembangan berikutnya (Nancy Angko, 2013: 10). Dalam penelitian ini, tahapan analisis dilakukan berdasarkan tahapan evaluasi dari pengembangan yang sebelumnya. Hasil evaluasi yang dilakukan terhadap 36 siswa dengan metode pembelajaran yang konvensional belum dapat meningkat motivasi dan prestasi belajar matematika menghitung luas dan keliling bangun datar, sehingga pembelajaran matematika pokok bahasan menghitung luas dan keliling bangun datar berdampak pada rendahnya nilai. Hal ini dibuktikan dengan nilai rata-rata siswa 58,33. Nilai tersebut jauh dibawah nilai KKM (Kriteria Ketuntasan Minimal), yaitu 70, dan dari 36 siswa terdapat 13 siswa (36,11\%) yang memperoleh nilai ketuntasan kelas yang itu meperoleh nilai $\geq 70$ sedangkan 23 siswa $(63,89$ $\%$ ) memperoleh nilai dibawah KKM yaitu memperoleh nilai $<70$. Dengan demikian, kriteria ketuntasan belum memenuhi indikator pencapaian. 


\begin{tabular}{ccccc}
\hline No & $\begin{array}{c}\text { Nilai Siswa } \\
(\mathrm{x})\end{array}$ & $\begin{array}{c}\text { Jumlah Siswa } \\
(\mathrm{y})\end{array}$ & $(\mathrm{x})(\mathrm{y})$ & Ket. \\
\hline 1 & 10 & 0 & 0 \\
2 & 20 & 0 & 0 \\
3 & 30 & 0 & 0 \\
4 & 40 & 8 & 320 \\
5 & 50 & 9 & 450 \\
6 & 60 & 6 & 360 \\
7 & 70 & 7 & 490 \\
8 & 80 & 6 & 480 \\
9 & 90 & 0 & 0 \\
10 & 100 & 0 & 0 \\
\hline Jumlah & \multicolumn{5}{c}{56,33} & 2100 \\
Rata-rata & & & \\
\hline
\end{tabular}

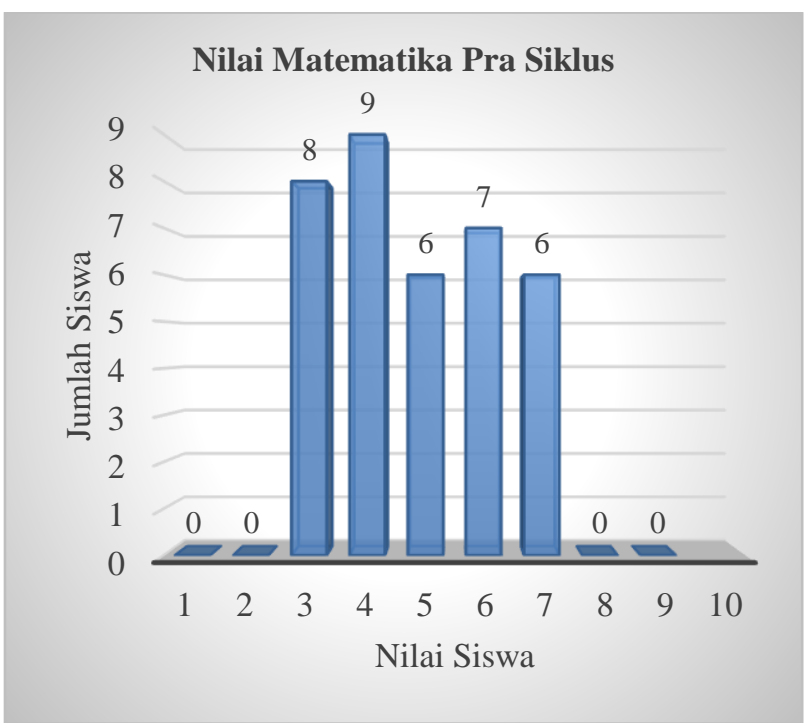

Gambar 2. Grafik Nilai Matematika Pra Siklus

Selanjutnya peneliti melakukan penelitian tindakan kelas siklus 1, yaitu dengan diterapkannya metode pembelajaran dengan menggunakan media realia. Artinya pada pembelajaran ini, guru menyediakan beberapa media realia (nyata) berupa bangun datar dan beberapa bangun datar yang ada disekitarnya.
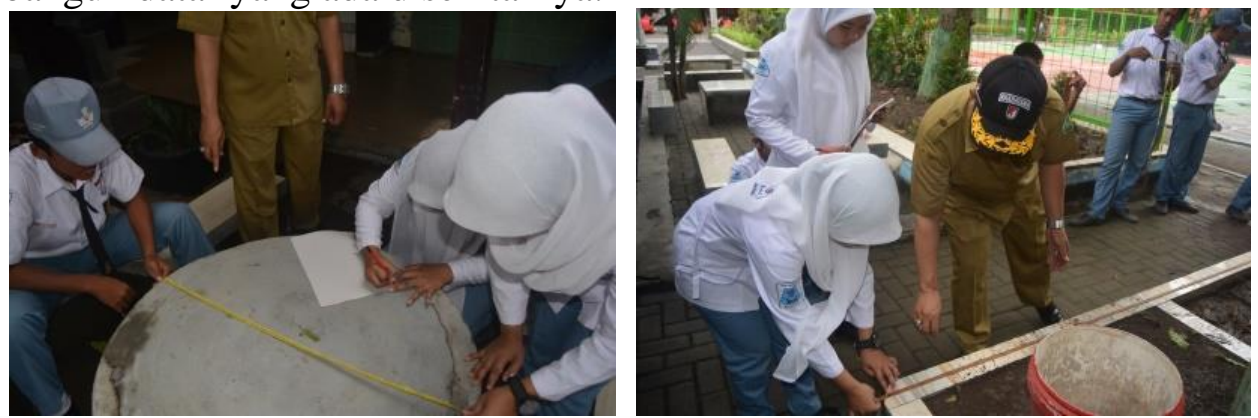

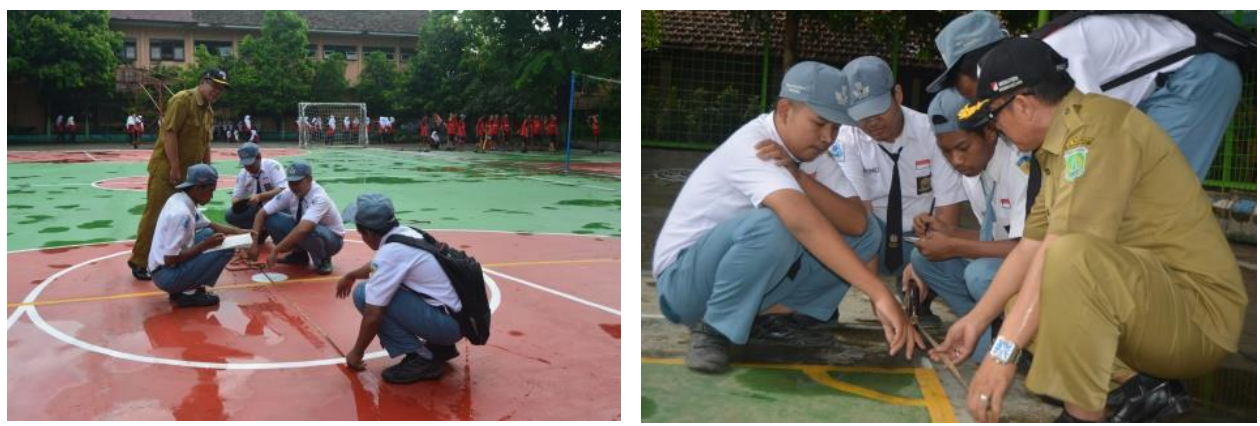

Gambar 3. Pelaksanaan Pembelajaran dengan media realian (nyata)

Pada akhir pembelajaran disampaikan kesimpulan proses pembelajaran pada hari ini dan peneliti/guru menyampaikan bahwa pada pertemuan berikutnya diadakan tes tertulis secara individu. Tes dilakukan untuk mengetahui sejauh mana keberhasilan siswa dalam pembelajaran matematika dengan menggunakan media realia dan dapat dilihat pada tabel 2 berikut :

Tabel 2. Nilai Matematika Siklus 1

\begin{tabular}{lcccc}
\hline No & $\begin{array}{c}\text { Nilai Siswa } \\
(\mathrm{x})\end{array}$ & $\begin{array}{c}\text { Jumlah Siswa } \\
(\mathrm{y})\end{array}$ & $(\mathrm{x})(\mathrm{y})$ & Ket. \\
\hline 1 & 10 & 0 & 0 & \\
2 & 20 & 0 & 0 & \\
3 & 30 & 0 & 0 & \\
4 & 40 & 2 & 80 & \\
5 & 50 & 5 & 250 & \\
6 & 60 & 7 & 420 \\
7 & 70 & 9 & 630 \\
8 & 80 & 10 & 800 \\
9 & 90 & 3 & 270 \\
10 & 100 & 0 & 0 \\
\hline Jumlah & \multicolumn{5}{c}{68,06} \\
Rata-rata & \multicolumn{5}{c}{2450} \\
\hline \multicolumn{5}{c}{} \\
\hline
\end{tabular}

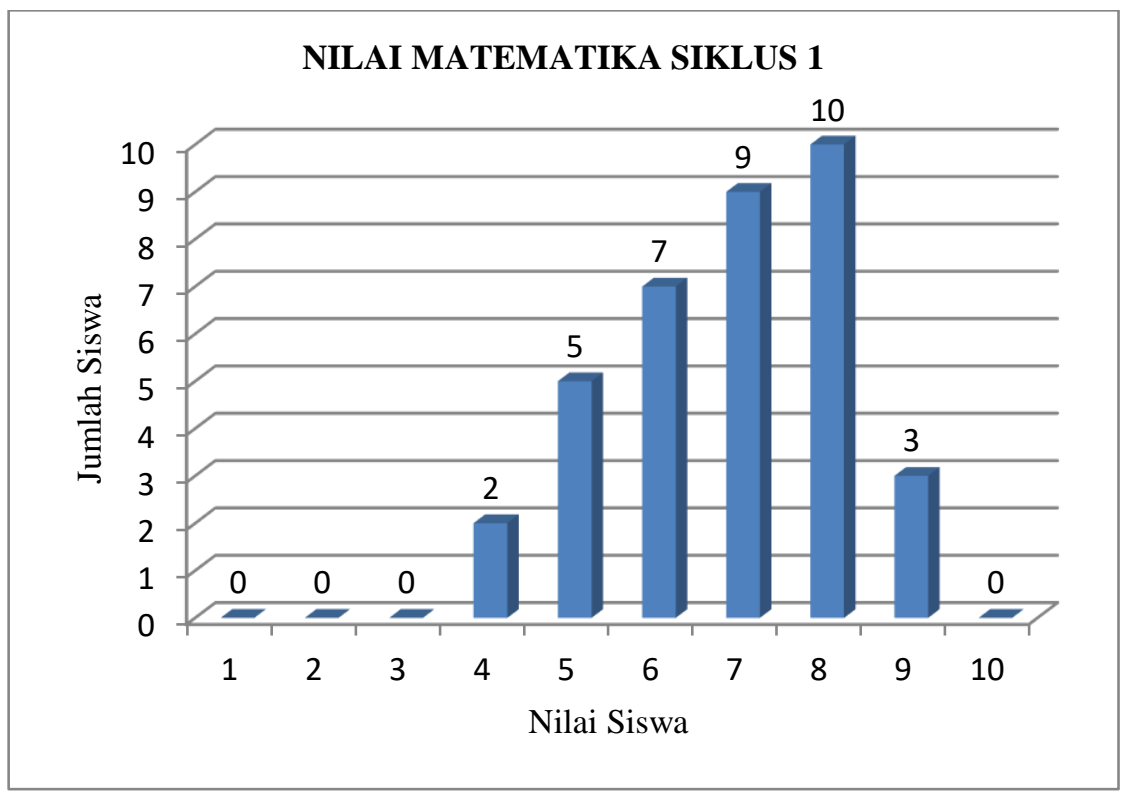

Gambar 4. Grafik Nilai Matematika Siklus 1 
Pada kegiatan ini ditemukan bahwa prestasi belajar dalam kegiatan siklus I ini masih belum maksimal, sesuai dengan tujuan pembelajaran yang diharapkan sehingga guru harus melakukan perbaikan ulang. Dari data evaluai / tes ditemukan nilai rata-rata kelas 68,06 dan terdapat 22 siswa $(61,11 \%)$ dari seluruh siswa berjumlah 36 memperoleh nilai 70 ke atas, sedangkan 14 siswa $(38,89 \%)$ dari seluruh siswa berjumlah 36 siswa masih memperoleh nilai dibawah 70. Karena jumlah siswa yang memperoleh nilai 70 ke atas kurang dari $80 \%$, maka perlu dilanjutkan perbaikan pembelajaran pada siklus II.

Setelah diadakan proses pembelajaran pada sikus II dengan menerapkan metode pembelajaran menggunakan media realia seperti pada siklus I, terdapat peningkatan yaitu motivasi belajar siswa semakin meningkat dengan ditandai dengan antusiasnya siswa dalam mengikuti pembelajaran. Dan dipertemuan berikutnya diadakan penilaian secara individu dalam bentuk tes tertulis. Adapun nilai akhir pada siklus II diperoleh seperti pada tabel 3 dan gambar 5 berikut:

Tabel 3. Nilai Matematika Siklus 2

\begin{tabular}{ccccc}
\hline No & $\begin{array}{c}\text { Nilai Siswa } \\
(\mathrm{x})\end{array}$ & $\begin{array}{c}\text { Jumlah Siswa } \\
(\mathrm{y})\end{array}$ & $(\mathrm{x})(\mathrm{y})$ & Ket. \\
\hline 1 & 10 & 0 & 0 & \\
2 & 20 & 0 & 0 & \\
3 & 30 & 0 & 0 & \\
4 & 40 & 0 & 0 & \\
5 & 50 & 1 & 50 & \\
6 & 60 & 3 & 180 \\
7 & 70 & 4 & 280 \\
8 & 80 & 11 & 880 \\
9 & 90 & 15 & 1350 \\
10 & 100 & 2 & 200 & \\
\hline \multicolumn{5}{c}{ Jumlah } \\
Rata-rata & 36 & 2940 \\
\hline
\end{tabular}

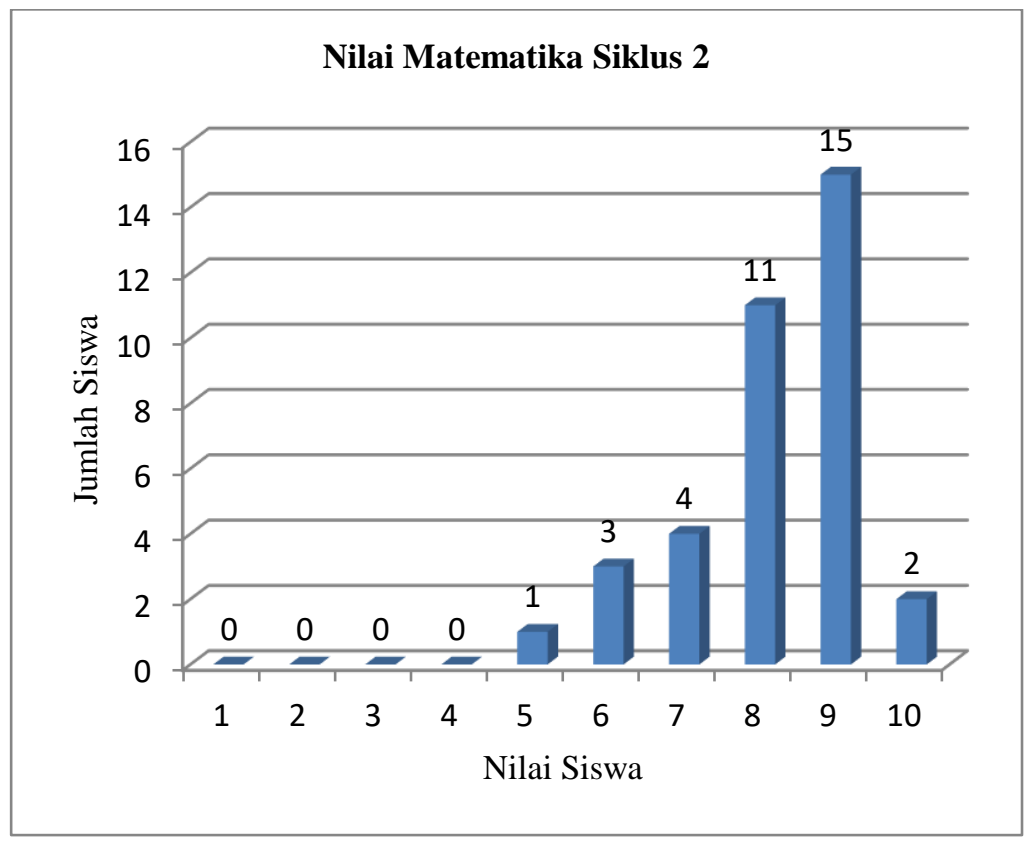

Gambar 5. Grafik Nilai Matematika Siklus 2 
Pada kegiatan ini ditemukan bahwa prestasi belajar dalam kegiatan siklus ini sudah maksimal, dan sesuai dengan tujuan belajar yang diharapkan. Dari data evaluasi / tes ditemukan nilai rata-rata kelas 81,67 dan terdapat 32 siswa $(88,89 \%)$ dari seluruh siswa berjumlah 36 memperoleh nilai 70 ke atas, sedangkan 4 siswa $(11,11 \%)$ dari seluruh siswa berjumlah 36 siswa masih memperoleh nilai dibawah 70. Karena jumlah siswa yang memperoleh nilai $70 \mathrm{ke}$ atas lebih dari $80 \%$, maka tidak perlu dilanjutkan perbaikan pembelajaran siklus III. Dari dua siklus yang dilakukan dalam penelitian ini terdapat perkembangan yang membaik, terbukti dari prolehan nilai tiap-tiap siklus, mulai dari pra siklus-siklus I-siklus II terdapat kenaikan yang signifikan dan meningkat ditandai dengan nilai rata-rata kelas yang semakin meningkat, seperti yang disajikan pada tabel 4 dan gambar 6 berikut:

Tabel 4. Nilai Matematika pada pra siklus, siklus 1 dan siklus 2

\begin{tabular}{ccccc} 
& \multirow{2}{*}{$\begin{array}{c}\text { Nilai Siswa } \\
(\mathrm{x})\end{array}$} & \multicolumn{3}{c}{ Jumlah siswa pada } \\
\cline { 3 - 5 } & & Pra Siklus & Siklus 1 & Siklus 2 \\
\hline 1 & 10 & 0 & 0 & 0 \\
2 & 20 & 0 & 0 & 0 \\
3 & 30 & 0 & 0 & 0 \\
4 & 40 & 8 & 2 & 0 \\
5 & 50 & 9 & 5 & 1 \\
6 & 60 & 6 & 7 & 3 \\
7 & 70 & 7 & 9 & 4 \\
8 & 80 & 6 & 10 & 11 \\
9 & 90 & 0 & 3 & 15 \\
10 & 100 & 0 & 0 & 2 \\
\hline
\end{tabular}

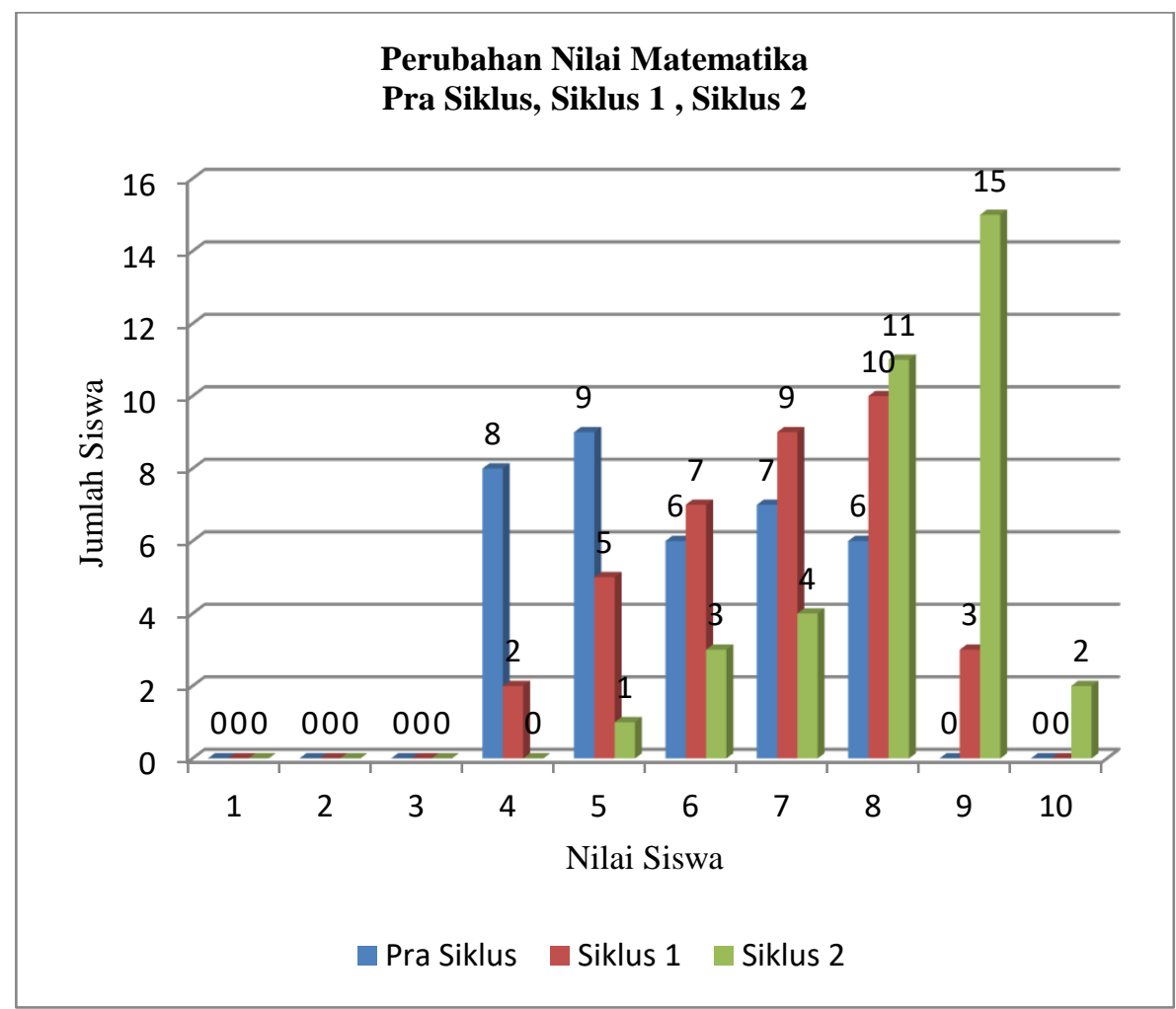

Gambar 6. Grafik Nilai Matematika pada prasiklus, siklus 1 dan siklus 2 
Hasil dari tindakan penerapan metode pembelajaran menggunakan media realia yang dilaksanakan dalam 2 siklus mampu meningkatkan prestasi belajar matematika pada siswa kelas XI Listrik 1 SMK Negeri 1 Bangil Tahun pelajaran 2019/2020. Kinerja guru dan siswa selama proses pembelajaran matematika pokok bahasan bilangan riil mengalami peningkatan. Indikator penilaian kinerja guru menurut Sudjana (2008) berupa pelaksanaan pra pembelajaran, membuka pembelajaran, menggali pengetahuan siswa, menyajikan materi pembelajaran, menggunakan media realia, membimbing diskusi, membimbing siswa presentasi, menguatkan siswa, dan menutup pelajaran. Kualitas kinerja guru selama proses pembelajaran menggunakan media realia dapat dikatakan efektif dan meningkat jika dilihat dari hasil nilai rata-rata kelas pada prasiklus, siklus 1 dan siklus 2 yang semakin meningkat, seperti yang tersajikan pada tabel 5 dan gambar 7 berikut ini:

Tabel 5. Kinerja guru

\begin{tabular}{llccc}
\hline No & Siklus & $\begin{array}{c}\text { Nilia } \\
\text { Min }\end{array}$ & $\begin{array}{c}\text { Nilai } \\
\text { Max }\end{array}$ & $\begin{array}{c}\text { Rata } \\
\text { rata }\end{array}$ \\
\hline 1 & Pra Siklus & 40 & 80 & 58,33 \\
2 & Siklus 1 & 40 & 90 & 68,06 \\
3 & Siklus 2 & 50 & 100 & 81,67 \\
\hline
\end{tabular}

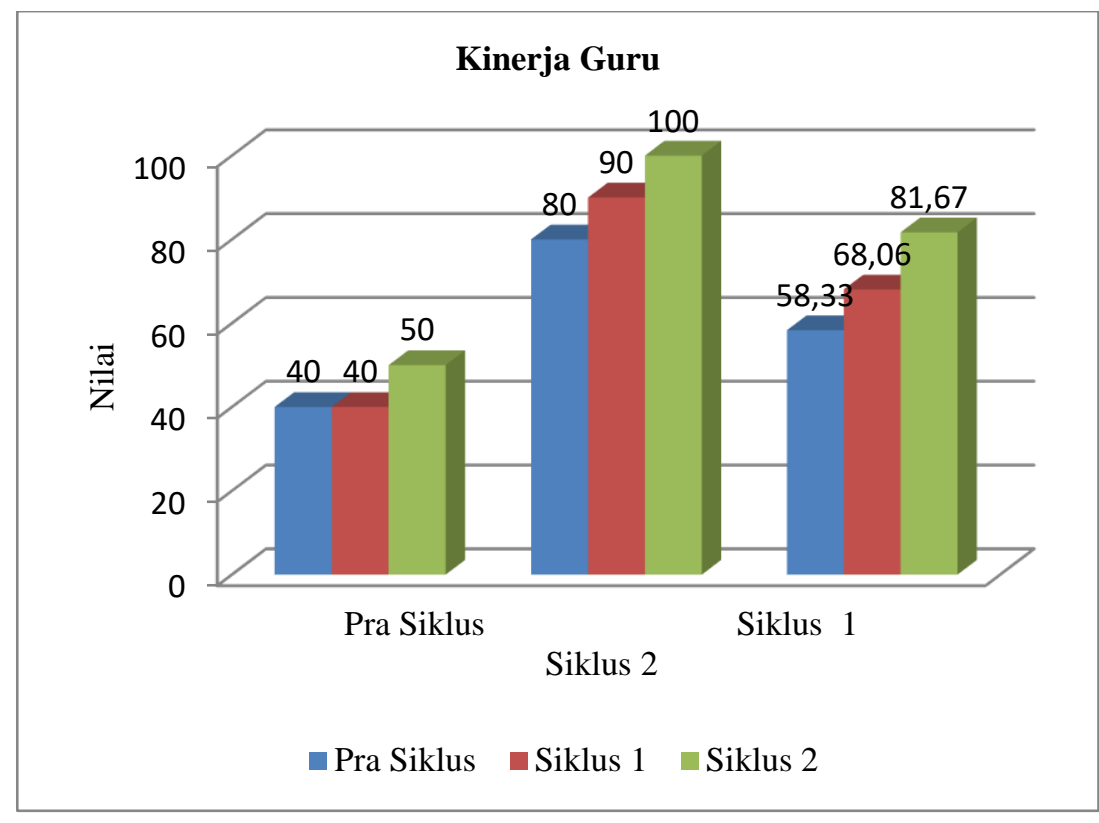

Gambar 7. Grafik Kinerja guru

Penilaian kualitas proses pembelajaran juga mencakup penilaian kinerja siswa dalam pembelajaran matematika pokok bahasan bilangan riil yang difokuskan pada (1) keaktifan siswa, (2) perhatian dan konsentrasi siswa, (3) minat dan motivasi siswa, dan (4) keterlibatan siswa dalam pembelajaran. Hasil yang didapatkan bahwa kinerja siswa mengalami peningkatan selama proses pembelajaran menggunakan metode media realia yaitu pada prasiklus terdapat 13 siswa $(36,11 \%)$ siswa yang mencapai nilai ketuntasan $\geq 70$ dan 23 
$(63,89 \%)$ memperoleh nilai dibawah 70 , pada siklus 1 terdapat 22 siswa $(61,11 \%)$ siswa yang mencapai nilai ketuntasan $\geq 70$ dan $14(38,89 \%)$ memperoleh nilai dibawah 70 dan pada siklus 2 terdapat 32 siswa $(88,89 \%)$ siswa yang mencapai nilai ketuntasan $\geq 70$ dan 4 $(11,11 \%)$ memperoleh nilai dibawah 70 seperti pada gambar 8 dibawah ini :

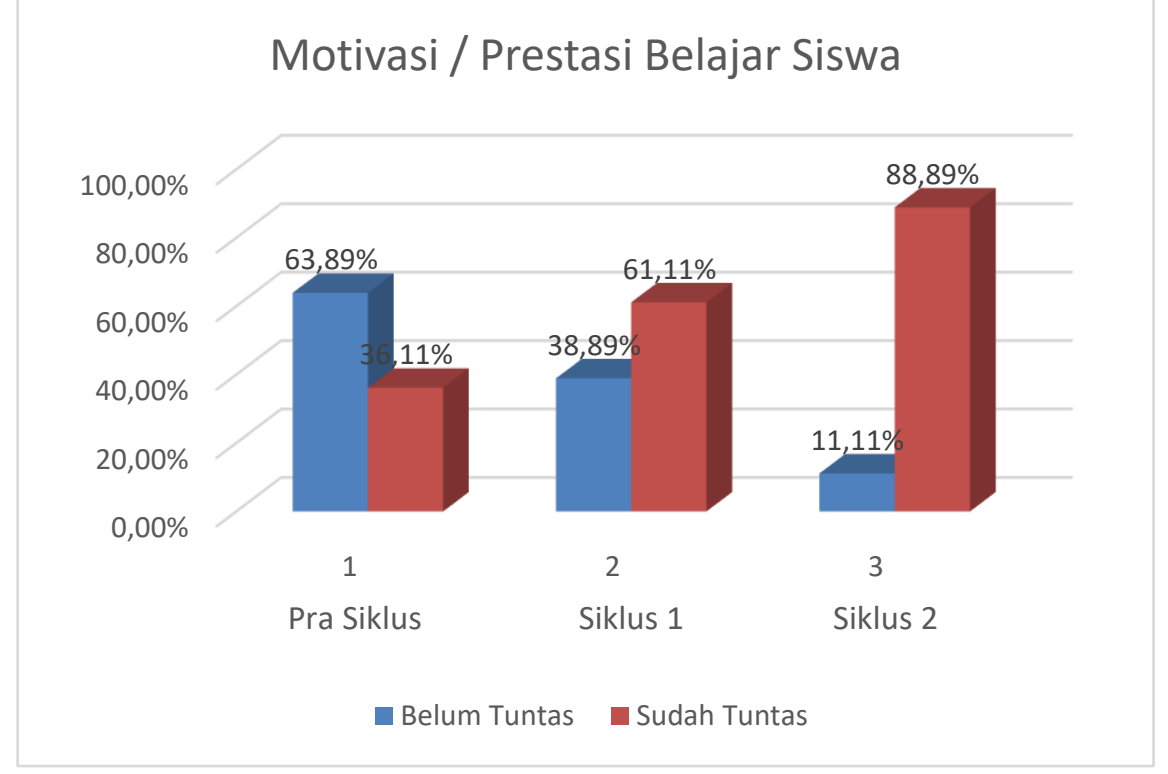

Gambar 8. Grafik Motivasi / Prestasi Belajar Siswa

Matematika adalah abstrak sehingga dalam memahami matematika sebaiknya menggunakan hal-hal yang nyata yang diketahui siswa agar terbangun koneksi antara siswa dengan apa yang diketahui guru (Gravemeijer : 2017), perlu diberikan kepada semua peserta didik mulai dari sekolah dasar, agar mampu berfikir logis, analitis, sistematis, kritis, dan kreatif, serta kemampuan bekerjasama (Martiningsih, 2014).

Bangun datar adalah bangun dua dimensi yang hanya memiliki panjang dan lebar, yaitu dibatasi oleh garis lurus atau lengkung. Macam-macam bangun datar sederhana antara lain : (1) Persegi atau bujur sangkar, (2) Persegipanjang, (3) Segitiga, (4) Trapesium, (5) Jajar genjang, (6) Lingkaran, (7) Layang-layang, dan (8) Belah ketupat. (Fajariyah, 2008 : 175181)

Media realia terdiri dari kata media dan kata realia (nyata). Menurut Azhar Arsyad (2013: 3) Kata Media berasal dari bahasa Latin Medius yang secara harfiah berarti tenga, perantara atau pengantar. Media adalah perantara atau pengantar pesan dari pengirim ke penerima. Media berasal dari bahasa latin yang merupakan bentuk jamak dari kata medium yang secara harfiah berarti perantara yaitu perantara sumber pesan dengan penerima pesan. Ditinjau dari pengertian komunikasi maka proses pembelajaran sebenarnya juga proses komunikasi. Dalam proses pembelajaran mengandung 5 unsur komunikasi yaitu : (1) Guru / pebelajar (komunikator), (2) Bahan pelajaran (isi pesan), (3) Alat untuk menyampaikan bahan pembelajaran (media), (4) Siswa/pebelajar (komunikan), dan (5) Efek (tujuan pembelajaran).

Benda realia (nyata) adalah segala sesuatu yang ada disekitar kita dan dapat digunakan untuk menyalurakan pesan (bahan pembelajaran) sehingga dapat merangsang perhatian, minat, pikiran dan perasaan siswa dalam kegiatan belajar untuk mencapai tujuan pembelajaran tertentu. Benda realia pada hakekatnya digunakan untuk mengkongkritkan pesan-pesan pembelajaran yang disampaikan oleh sumber pesan (guru) kepada penerima pesan (siswa) dengan maksud agar pesan-pesan tersebut dapat diserap dengan cepat dan tepat sesuai dengan tujuannya. (Winataputra, dkk. 1997:5.4)

Media realia (nyata) sangat diperlukan untuk mempertunjukkan benda asli menyerupai bangun datar yang ada di sekeliling kita (kelas) agar siswa lebih memahami konsep matematika terutama kompetensi dasar menghitung luas dan keliling bangun datar 
sederhana. Penggunaan media realia (nyata) merupakan cara penyajian pelajaran dengan meragakan atau mempertunjukan benda realia yang ada disekitar kita atau didalam kelas kepada siswa untuk mempermudah pemahaman materi yang sedang dipelajari, baik sebenarnya ataupun tiruan, yang sering disertai dengan penjelasan lisan. Dengan penggunaan benda kongkrit, proses penerimaan siswa terhadap pelajaran akan lebih berkesan secara mendalam, sehingga membentuk pengertian dengan baik dan sempurna. Juga siswa dapat mengamati dan memperhatikan apa yang diperlihatkan selama pelajaran berlangsung.

Kelebihan menggunakan pembelajaran menggunakan media realia antara lain: (1) Dapat membuat pengajaran menjadi lebih jelas dan lebih realita, (2) Siswa lebih mudah memahami apa yang di pelajari, (3) Proses pengajaran lebih menarik, dan (4) Siswa dirancang untuk aktif mengamati, menyesuaikan antara teori dengan kenyataan, dan mencoba melakukannya sendiri. Sedangkan kekurangan pembelajaran menggunakan media realia antara lain: (1) Penggunaan benda realia memerlukan persiapan yang teliti dan penggunaannya memerlukan waktu yang lama, (2) Proses belajar mengajar membutuhkan waktu yang lebih banyak, dan (3) Persiapan yang kurang teliti dan kurang tepat akan meyebabkan siswa melihat suatu tidak sesuai dengan keadaan sebenarnya.

Manfaat pembelajaran menggunakan media realia, antara lain: (1) Pertama, dapat dipergunakan untuk memberikan ilustrasi dalam menjelaskan informasi kepada anak. Bagi anak melihat bagaimana sesuatu lebih menanik, dan merangsang perhatian, serta lebih menantang daripada hanya mendengar penjelasan guru, dan (2) Kedua, penggunaan benda realia dapat membantu meningkatkan daya pikir anak terutama daya pikir anak dalam peningkatan kemampuan mengenal, mengingat, berpikir konvergen. dan berpikir evaluatif.

Belajar adalah proses mencari jawaban dari yang tidak tahu menjadi tahu. Menurut Reg Revans (1998), belajar adalah proses menanyakan sesuatu yang berawal dari ketidaktahuan tentang apa yang dilakukan. Di dalam Kamus Besar Bahasa Indonesia menyebutkan belajar adalah berusaha memperoleh kepandaian atau ilmu (1993:13). Sedangkan belajar menurut Suharsimi Arikunto (1993:19) adalah suatu proses yang terjadi karena adanya usaha untuk mengadakan perubahan terhadap diri manusia yang melakukan, dengan maksud memperoleh perubahan dalam dirinya, baik berupa pengetahuan, keterampilan, ataupun sikap.

Dari beberapa pendapat di atas dapat disimpulkan bahwa belajar merupakan suatu perubahan tingkah laku dalam berbagai aspek kepribadian, (yang idealnya) perubahan tersebut merupakan perubahan positif, diperoleh karena yang bersangkutan menghendaki perubahan, dan perubahan itu dicapai melalui tahapan latihan dan atau pengalaman.Menurut Mulyono Abdurrahman (2003:37) "Prestasi belajar adalah kemampuan yang diperoleh anak setelah melalui kegiatan belajar". Dalam kegiatan pembelajaran tujuan yang ingin dicapai ditentukan sebelumnya. Anak yang dikatakan berhasil adalah mereka yang dapat mencapai tujuan-tujuan pelajaran yang telah ditentukan sebelumnya.

Dimyati dan Mujiono (2006:3) memaparkan bahwa "Prestasi belajar merupakan hasil dari suatu interaksi tindak belajar dan tindak mengajar". Prestasi belajar merupakan pencapaian tujuan pengajaran dan kemampuan mental siswa. Setelah selesai mempelajari materi, diadakan evaluasi belajar untuk mengetahui tingkat pencapaian tujuan pembelajaran yang telah ditentukan sebelumnya, sebelum dilanjutkan pada jenjang yang lebih tinggi. Hal senada juga disampaikan oleh Nana Sudjana (2008) bahwa prestasi belajar adalah kemampuan-kemampuan yang dimiliki siswa atau mahasiswa setelah ia menerima pengalaman belajarnya.

Berdasarkan teori di atas dapat disimpulkan bahwa prestasi belajar adalah kemampuan yang diperoleh anak setelah melalui kegiatan belajar. Prestasi belajar merupakan penguasaan berbagai macam keterampilan, pengetahuan setelah siswa memperoleh pengalaman belajar. Dalam kegiatan pembelajaran tujuan yang ingin dicapai ditentukan sebelumnya. Anak yang dikatakan berhasil adalah mereka yang dapat mencapai tujuan-tujuan pembelajaran yang telah ditentukan sebelumnya. 
Prestasi belajar siswa dipengaruhi oleh dua faktor utama yakni faktor dari dalam diri siswa dan faktor yang datang dari luar siswa, yaitu (a) Faktor dari dalam diri siswa , dimana prestasi belajar siswa di sekolah $70 \%$ dipengaruhi oleh siswa dan 30\% dipengaruhi oleh lingkungan (Rusna Ristasa, 2003). Berkaitan dengan faktor diri siswa yaitu motivasi, minat, sikap perhatian, kebiasaan belajar, ketekunan, kondisi sosial ekonomi, dan kondisi fisik dan psikis. Dan (b) Faktor dari luar siswa yang dominan mempengaruhi prestasi belajar adalah kualitas pengajaran. Yang dimaksud kualitas pengajaran adalah tinggi/ rendahnya atau efektif/tidaknya proses pembelajaran dalam mencapai tujuan. Metode pembelajaran juga sangat berpengaruh dalam pencapaian prestasi belajar. Pemilihan metode yang tepat mutlak diperlukan agar pembelajaran menjadi menyenangkan dan berkesan bagi siswa yang akhirnya dapat meningkatkan prestasi belajar siswa.

Pada permasalahan telah disajikan bahwa mempelajari matematika tentang menghitung luas dan keliling bangun datar tidaklah mudah. Pada penelitian yang menerapkan metode pembelajaran dengan menggunakan media realia dianggap mampu meningkatkan motivasi dan prestasi belajar matematika. Metode pembelajaran yang baik dan dapat diterapkan dengan benar akan menghasilkan kualitas proses dan hasil pembelajaran yang baik pula. Peningkatan indikator setiap siklus membuktikan bahwa pemilihan metode pembelajaran yang tepat dapat mengatasi kesulitan belajar yang dialami siswa kelas XI Listrik 1, yaitu kesulitan belajar matematika pokok bahasan menghitung luas dan keliling bangun datar. Penggunaan metode pembelajaran yang tepat dibantu dengan media atau alat pembelajaran dapat mendorong siswa untuk berfikir lebih jernih dan nyata sehingga dapat membantu siswa dalam mengembangkan ide dan gagasannya. Hal tersebut terlihat pada perolehan hasil pekerjaannya persiklus yang semakin meningkat.

Sejalan dengan proses pembelajaran, Ode (2014) berpendapat bahwa proses pengajaran dan pembelajaran sangat penting disemua tingkat perkembangan pendidikan. Jika terarah dan terencana dengan baik, maka metode pembelajaran dengan menggunakan media realia ini bisa membuat siswa lebih aktif dan menyenangkan dalam mengikuti pembelajaran matematika yang dianggap tidak mudah. Menurut Bahri (2012) pemilihan metode pembelajaran yang tepat perlu menyesuaikan karakteristik siswa sehingga dapat memotivasi siswa untuk aktif belajar dan membantu pengetahuan mereka sendiri tanpa tergantung kepada guru yang pada akhirnya dapat berdampak dalam peningkatan prestasi belajar siswa itu sendiri. Begitu juga aspek kreativitas seseorang juga merupakan salah satu modal bagi siswa dan guru untuk mendapatkan pembelajaran yang optimal (Koesnandar, 2020).

Penelitian yang relevan dilakukan oleh Kaiyan (2017) dengan judul Upaya Peningkatan Prestasi Belajar Menghitung Luas dan Keliling Bangun Datar Menggunakan Media Realia Siswa Kelas IV SDN Jemirahan Jabon Sidoarjo Tahun Pelajaran 2016/2017. Penelitian dilakukan terhadap 28 siswa dengan hasil pada siklus I terdapat 9 siswa $(28,1 \%)$ mencapai nilai ketuntasan yaitu $\geq 70$ dengan rata-rata kelas 58,75 dan pada sikius II diperoleh 28 siswa $(87,5 \%)$ mencapai nilai ketuntasan yaitu $\geq 70$ dengan rata-rata kelas 86,88,. Dari hasil perbaikan pembelajaran yang dilaksanakan oleh peneliti maka dapat ditarik kesimpulan bahwa penggunaan media realia dapat meningkatkan prestasi menghitung belajar luas dan keliling bangun datar siswa kelas IV SDN Jemirahan kecamatan Jabon Kabupaten Sidoarjo Tahun Pelajaran 2016/2017. Penelitian yang sama juga dilakukan oleh Kartini pada tahun 2015 dengan judul penggunaan media nyata untuk meningkatkan hasil belajar siswa dalam pembelajaran matematika di kelas 1 SD Negeri 33 Ikatan Tungga. Pada penelitian tersebut ada peningkatan hasil belajar matematika yaitu nilai rata-rata pada siklus I $(63,70)$, siklus II $(77,03)$ dan siklus III $(80,37)$ dengan kesimpulan media nyata dapat meningkatkan hasil belajar siswa dalam pembelajaran matematika di kelas 1 SD Negeri 33 Ikatan Tungga. Penelitian yang sama juga dilakukan oleh Edo Dwi Cahyo pada tahun 2012 dengan judul peningkatan aktivitas dan hasil belajar siswa menggunakan media realia pada pembelajaran IPS kelas IV SDN 08 Metro Selatan Tahun Pelajaran 2011/2012. Pada penelitian tersebut nilai rata-rata kelas siklus I $(68,70)$, siklus II $(75,03)$, dan siklus III $(81,07)$ dengan 
kesimpulan media realia dapat meningkatkan aktivitas dan hasil belajar siswa pada pembelajaran IPS kelas IV SDN 08 Metro Selatan tahun pelajaran 2011/2012.

\section{KESIMPULAN}

Berdasarkan hasil penelitian dapat disimpulkan bahwa penggunaan metode pembelajaran dengan menggunakan media realia dapat meningkatkan motivasi dan prestasi belajar matematika pokok bahasan menghitung luas dan keliling bangun datar pada siswa kelas XI Listrik 1 SMK Negeri 1 Bangil Kabupaten Pasuruan Tahun Pelajaran 2019/2020. Hal ini dapat dibuktikan dengan meningkatnya hasil prestasi belajar yang diperoleh mulai dari pra siklus, siklus 1 dan siklus 2 . Berdasarkan hasil penelitian, maka saran-saran yang disampaikan adalah untuk meningkatkan motivasi dan prestasi belajar siswa dapat menggunakan metode pembelajaran dengan media realia pada pelajaran matematika maupun pelajaran lainnya.

\section{DAFTAR PUSTAKA}

Abdurrahman, M. 2003. Pendidikan Bagi Anak Berkesulitan Belajar. Jakarta : Rineka Cipta Angko, N, dkk. 2013. Pengembangan Bahan Ajar dengan Model ADDIE untuk Mata Pelajaran Matematika Kelas 5 SDS Mawar Sharon Surabaya. Kwangsan, Jurnal Teknologi Pendidikan. Vol. 1, No. 1, DOI: https://doi.org/10.31800/jtp.kw.v1n1.p1-15 Arikunto, S., dkk. 2007. Penelitian Tindakan Kelas. Jakarta: Bumi Aksara.

Bahri, S.D. 2002. Strategi Belajar Mengajar. Jakarta : Rineka Cipta

Bahri, S. D. 2012. Guru \& Anak Didik dalam Interqaksi Edukatif Cet ke-3, Jakarta : Rineka Cipta , hal 405

Dimyati, Mudjiono, 2006. Belajar dan Pembelajaran. Jakarta: PT. Rineka Cipta

Dwi, C.E, 2012. Skripsi : Peningkatan Aktivitas Dan Hasil Belajar Siswa Menggunakan Media Realia Pada Pembelajaran IPS Kelas IV SDN 08 Metro Selatan Tahun Pelajaran 2011/2012. Lampung : Fakultas Keguruan dan Ilmu Pendidikan Universitas Lampung

Gravemeijer, K. 2017. How Concrete Is Concrete? IndoMS JME

Hudoyo, H. 2005. Teori Belajar untuk Pengajaran Matematika. Jakarta: Depdikbud

Kaiyan. 2017. PTK. Upaya Peningkatan Prestasi Belajar Menghitung Luas dan Keliling Bangun Datar Menggunakan Media Realia Siswa Kelas IV SDN Jemirahan Jabon Sidoarjo Tahun Pelajaran 2016/2017. Sidoarjo: tidak dipublikasikan/disimpan diperpustakaan sekolah

Kartini, L. 2015. Artikel Penelitian : Penggunaan Media Nyata Untuk Meningkatkan Hasil Belajar Siswa Dalam Pembelajaran Matematika di SD. Pontianak : Universitas Tanjungpura

Koesnandar, A. 2020. Pengembangan model pembelajaran inovatif berbasis teknologi informasi dan komunikasi (TIK) sesuai kurikulum 2013. Kwangsan, Jurnal Teknologi Pendidikan, Vol.8, No.1. DOI: https://doi.org/10.31800/jtp.kw.v8n1.p33--61

Martiningsih, R.R. 2014. Peningkatan Hasil Belajar Pola Bilangan dengan Aplikasi Ispring. Kwangsan, Jurnal Teknologi Pendidikan. Vol. 2, No. 2. DOI: https://doi.org/10.31800/jtp.kw.v2n2.p134-145

Mukhlis, A. (ed), 2000. Penelitian Tindakan Kelas, Makalah Panitia Penulisan Karya Ilmiah untuk Guru-guru se-Kabupaten Tuban.

Ngalim P. 2006. Prinsip-Prinsip dan Teknik Evaluasi Pengajaran, Bandung: Remaja Rosdakarya

Ode, E.O. 2014. Impact of audio-visual (AVS) resources on teaching and learning in some selected private secondary school in makurdi. International Journal of Research in Humanities, Art and Literature (Impact Journal), 5(2), 195-202

Pusat Pembinaan dan Pengembangan Bahasa. 1995. Kamus Besar Bahasa Indonesia (KBBI). Jakarta: Balai Pustaka. 
Revans, R. 1998. Action Learning. New York: Hart Publishing Co.

Ristasa, R.A. 2003. Pedoman Penyususunan Proposal dan Penulisan Laporan Penelitian Tindakan Kelas. Purwokerto: Kementerian Pendidikan dan Kebudayaan Universitas Terbuka

Sudjana, N. 2008. Penilaian hasil belajar mengajar. Bandung : Rosda Karya

Winataputra, H.U.S, dkk. 1997. Teori Belajar dan Model-model Pembelajaran. Jakartya: Dirjen Dikti, Depdikbud

Winataputra, H, U, S. 2005. Strategi Belajar Mengajar. Jakarta : Depdikbud. 